\title{
The Development of Digital Payment Systems in Indonesia: a Review of Go-Pay and Ovo E-Wallets
}

\section{Rosita Widjojo*}

\section{Summary}

The development of new digital payment systems has been on the rise in Indonesia in the past two years and these digital payments are pioneered by transportation apps for the ease of payment when customers use these apps for mobility purposes. In the wake of Covid-19, digital payments are frequently used during quarantine, as people do their daily transactions online. In the form of mobile payments, these cashless transactions are becoming increasingly popular nowadays as well. The rise of Go-Pay and OVO, as the most popular e-wallets in Indonesia, emerged from the online transportation apps of Go-Jek and Grab, respectively. They come into existence due to some unexpected factors: fintech development, internet access and smartphone penetration, the majority of unbanked population in Indonesia, and transportation apps. This paper reviews Go-Pay and OVO as Indonesia's major e-wallets, to compare and contrast both apps using secondary data, and to conclude on how e-wallets will become the payment trend post-Covid-19 in running daily business transactions.
Keywords: digital payments, e-commerce, e-wallets, transportation apps

JEL: L22, L86, M13, M31, O33

\section{Introduction}

he emergence of new digital
payment systems has been on a rise in Indonesia in the past two years and these digital payments are pioneered by transportation apps and other non-bank enterprises. Previously, financial institutions such as commercial banks issued e-money cards as a form of cashless payments. In this case you can transfer some amount of money from your bank account to your e-money cards and use that for to buy things and to pay toll fees (in highways), commuter line train tickets, TransJakarta bus tickets, and many more. As public transportation in Indonesia, especially in big cities, is not very well-developed, traffic congestion is a common sight in big cities, especially in Jakarta. Despite the availability of the commuter line (trains between Jakarta and its surrounding suburbs) and TransJakarta bus lines, it is still insufficient to provide easy, cheap and comfortable public transportation for approximately 10 million people. In many cases, traffic jams in Jakarta can last for hours being stuck in the road. Such conditions occur in other big cities as well,

\footnotetext{
University of Sopron - Szechenyi Istvan Doctoral School Faculty of Economics, Hungary
} 


\section{Articles}

such as Surabaya, Medan, and Bandung. This lack of sufficient public transport leads to preferences on using private vehicles (cars or motorcycles) to commute, resulting in severe traffic congestions that can last for hours.

Startups see this condition as an opportunity and created apps to solve people's mobility in big cities. One startup company called Go-Jek created apps that could help people go from one place to another with motorcycles. Due to Indonesia's climate where the monsoon season can last longer, Go-Jek created facilities to help the transportation of people by using cars instead of motorcycles, so Go-Car evolved from the same apps platform. During this period there were many transportation apps that came into the market, such as Uber, Go-Jek, Grab and many more, including one big taxi company in Indonesia, Blue Bird. However, in just a few years, Uber became unpopular, giving the momentum for Go-Jek and Grab, now the two most popular transportation apps. Customers who use these apps, Go-Jek or Grab, can use their payment facilities, Go-Pay and OVO respectively, in which customers can put some money in their Go-Jek and Grab accounts, use the transportation apps to go someplace, and pay using the Go-Pay or OVO facilities without the need of any cash payments. A year later, the rise of Go-Pay and OVO is not only limited to pay for a ride, but can also be used to shop in merchants as a form of payment, besides the usual cash, debit cards or credit cards. Such apps are especially useful during the Covid-19 quarantine, and the trend of payments is shifted more to online purchases and online delivery rather than using transport due to the limitation of mobility. However, despite the limited mobility of people and a decline in transporation use, Go-Jek and Grab still maintain a considerable market share from other services provided in their apps. There has not been a lot of recent research about digital payments and e-wallets in Indonesia, specifically on Go-Pay and OVO, so this paper will review how Go-Pay and OVO as non-financial institutions managed to place themselves at the top of digital payments in Indonesia.

\section{Literature Review}

\subsection{The Rise of Indonesia's E-commerce and Digital Payments}

Indonesia's growing digital economy has also contributed significantly to the nation's growth and the republic is digitizing rapidly. According to Statista (2019), with approximately 107 million internet users, Indonesia is one of the biggest online markets worldwide. It is predicted that by 2023 , internet users in Indonesia will reach around 150 million, which is a huge potential for e-commerce. Statista (2019) also reports that as of June 2019, online penetration in the country stood at slightly over 50 percent. Popular online activities include mobile messaging and social media. The most popular social network in Indonesia is Facebook with 81 percent of the online populatioin using the platform. Mobile internet usage is undergoing double-digit growth rates and currently stands at over 30 percent among the population. Social media usage in the country is also among the highest in the world. 
Figure 1. Number of Internet Users in Indonesia from 2017 to 2023

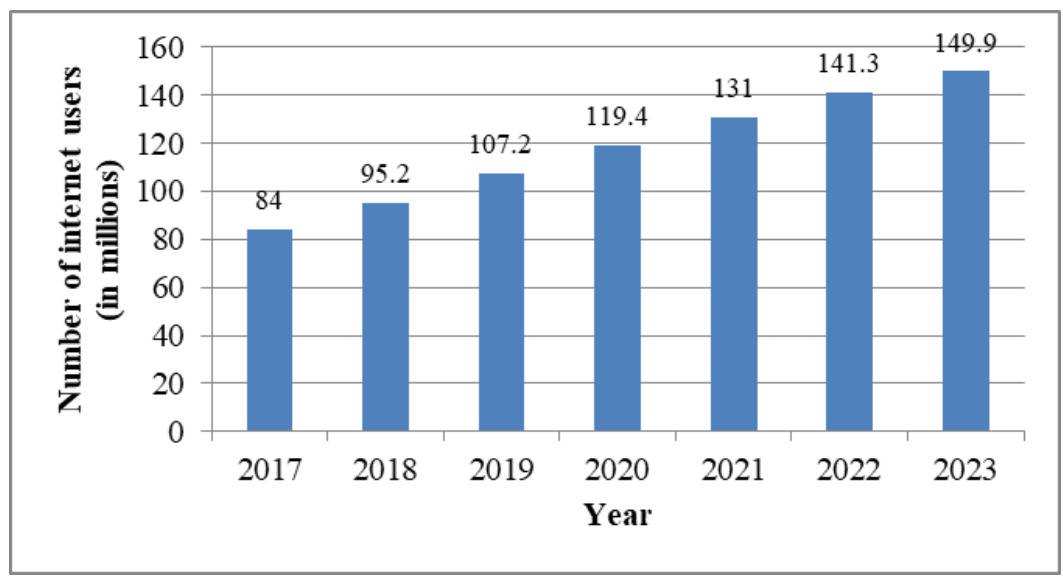

Source: Edited from www.statista.com, 2019

Among the main reasons e-commerce has seen a sharp increase in Indonesia is the rapid increase in smartphone usage. As opposed to online users in Europe or the United States (US), most Indonesians have skipped the digital evolution from personal computers to laptops and tablets, and gone straight to smartphones. Smartphones are also much more affordable than desktop computers and laptops which makes them very accessible to a vast majority of Indonesians. With more than 40 percent of its population on smartphones, about 70 percent of the country's internet traffic comes from these devices. The McKinsey Global Payment report (2019) highlighted that almost 75 percent of Indonesia's online shoppers use mobile devices - a much higher rate than neighbouring Malaysia (62 percent) and the US (39 percent).

On the other hand, the growth of informal commerce can be attributed to the digitalsavvy youth of Indonesia. Statistics indicate that Indonesian youths (and to a certain extent their elders) are avid users of social media. The country has the fourth largest number of Facebook users in the world with 122 million people and has one of the largest populations of Instagram users in the region. Indonesia is also the fifth-largest country in terms of Twitter users. With so many social media users, it is no surprise how big informal commerce is in the country. For social commerce to thrive, it requires users that are familiar with the ins and outs of social media.

Indonesia's flourishing e-commerce sector, however, cannot just be attributed to its growing base of consumers. Credit must also be given to the growing number of online sellers too. According to JP Morgan (2019), the number of online sellers in Indonesia has doubled every year for the past three years and reached a total of 4.5 million active sellers in 2017. About 99 percent of these are microenterprises and half of them are online-only businesses with no physical store presence. Online commerce has made it extremely easy for many Indonesians to start their own business and entrepreneurship has seen a sharp rise in the country. Not only does it encourage a vibrant marketplace but also gives people a way out of their socioeconomic woes. Meanwhile, e-commerce in Indonesia will only get bigger. The Indonesian e-commerce market is projected to grow eightfold from 2017 to 2022 with e-tail spending growing from US $\$ 5$ billion to US $\$ 425$ billion. Social commerce spending is expected to grow from US\$3 billion to as much as US\$25 billion (JP Morgan, 2019). As 


\section{Articles}

more digitalization is expected to take place, the digital economy could well be one of the main pillars of Indonesia's economy in the future.

Table 1. Indonesia's e-commerce Facts

\begin{tabular}{|l|l|}
\hline Population & $\mathbf{2 6 4}$ million \\
\hline Average age & 30.5 years \\
\hline Gross domestic product & \$1 trillion \\
\hline E-commerce market value & $\$ 13.6$ billion \\
\hline Mobile commerce market size & $\$ 7.1$ billion \\
\hline $\begin{array}{l}\text { Mobile commerce as a } \\
\text { percentage of e-commerce } \\
\text { market size }\end{array}$ & $52 \%$ \\
\hline Internet penetration & $32.3 \%$ \\
\hline Smartphone penetration & $40 \%$ \\
\hline Bank account penetration & $48 \%$ \\
\hline Card penetration per capita & 0.66 \\
\hline
\end{tabular}

Source: www.jpmorgan.com, 2019

\subsection{The Supporting Regulatory Environment}

The regulatory environment for digital payments in Indonesia are supported by two main entities: Bank Indonesia (Indonesia's central bank) and Otoritas Jasa Keuangan (OJK) or Indonesian Financial Services Authority. Bank Indonesia's primary function is geared towards monetary policies it has taken matters relating to payments under its regulatory scope, arguing that it has a big direct impact on the monetary stability. OJK functions as a supervisory arm of the government to regulate the financial services sector. Within the fintech environment, OJK oversees P2P lending, crowdfunding, digital banking, insurtech, fintech in capital markets, online financing, data security and of course consumer protection.

Table 2. Fintech Indonesia Regulatory Environment

\begin{tabular}{|c|c|c|}
\hline BANK INDONESIA & $\begin{array}{l}\text { OTORITAS } \\
\text { JASA } \\
\text { KEUANGAN }\end{array}$ & KEMKOMINFO \\
\hline $\begin{array}{l}\text { Bank of Indonesia } \\
\text { (Central Bank) }\end{array}$ & $\begin{array}{c}\text { Indonesia Financial Services } \\
\text { Authority (0JK) }\end{array}$ & $\begin{array}{l}\text { The Ministry of Communication } \\
\text { and Informatics (MOCIT) }\end{array}$ \\
\hline $\begin{array}{l}\text { - eWallets } \\
\text { - eMoney } \\
\text { - Payment gateways } \\
\text { - Principals } \\
\text { - Switching companies } \\
\text { - Card issuers and acquirers } \\
\text { - Clearing houses } \\
\text { - Settlement agencies } \\
\text { - Cryptocurrencies and blockchain } \\
\text { - National payment gateway } \\
\text { - Support for payment transactions, e.g. } \\
\text { ATM, EDC and data centers }\end{array}$ & $\begin{array}{l}\text { - Peer-to-peer (P2P) lending } \\
\text { - Crowdfunding } \\
\text { - Digital banking } \\
\text { - Insurtech } \\
\text { - Fintech in capital markets } \\
\text { - Venture capital } \\
\text { - Online financing } \\
\text { - Data security } \\
\text { - Consumer protection }\end{array}$ & $\begin{array}{l}\text { - Telecommunications } \\
\text { - Information technology } \\
\text { - Aspects of fintech that fall under } \\
\text { information technology }\end{array}$ \\
\hline
\end{tabular}

Source: www.fintech.sg, 2019

According to the Global Payment Trends report from JP Morgan (2019), cards are the dominant payment method in Indonesia when shopping online, taking a 34 percent share of the market with an actual low card usage, which counts for 0.59 debit cards per capita and 0.07 credit cards per capita. Visa ${ }^{\circledR}$ and Mastercard® are both well-recognized and 


\section{Articles}

utilized brands, and cards will continue to hold the pre-eminent position in the marketplace, growing at a compound annual growth rate of 39 percent to 2021.

Bank penetration in Indonesia is $48 \%$, leaving significant room for growth in the debit card market. Bank transfers are the second most-used e-commerce payment method in Indonesia, accounting for just over a quarter $(26 \%)$ of sales. However, regarding the emerging trend of digital wallets, bank transfers is expected to slightly decline by
The Development of Digital Payment Systems in

Indonesia: a Review of Go-Pay and Ovo E-Wallets

2021, by which point it will be overtaken by digital wallets. Currently, digital wallets are the third most-used e-commerce payment method in Indonesia and gained considerable popularity. Fostered by rising smartphone penetration, JP Morgan (2019) mentioned that digital wallets are used for one in five of all online shopping in Indonesia. Popular brands include PayPal ${ }^{\circledR}$ and domestic brand Go-Pay, the digital wallet arm of a major Indonesian e-commerce success story, the e-commerce app Go-Jek (fintechnews.sg).

Figure 2. Preferred e-commerce methods (sales, in billions of USD)

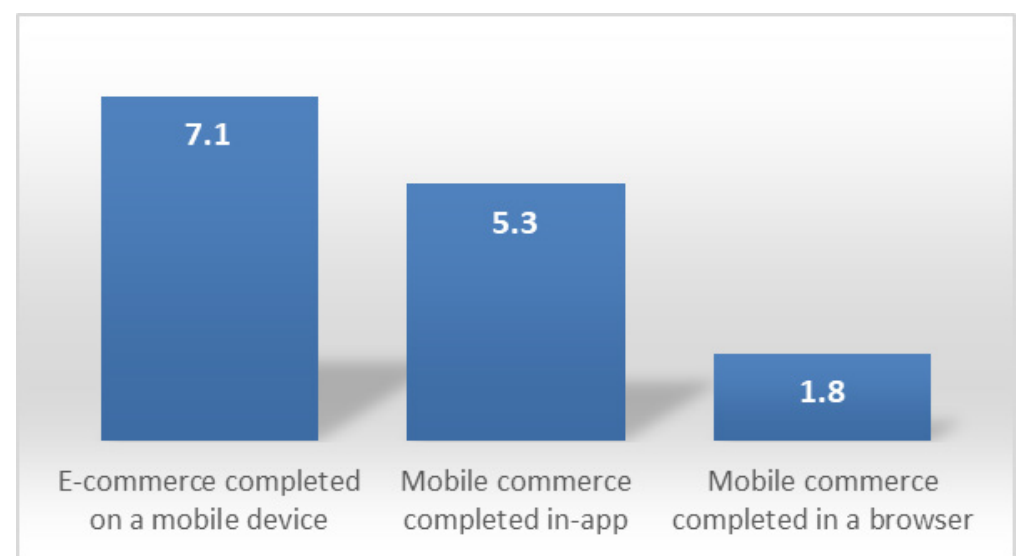

Source: JP Morgan 2019 Payments Trends - Global Insights Report: data provided by JP Morgan Merchant Services by Edgar, Dunn and Company via EDC Analysis

Figure 3. E-commerce payment method split by value

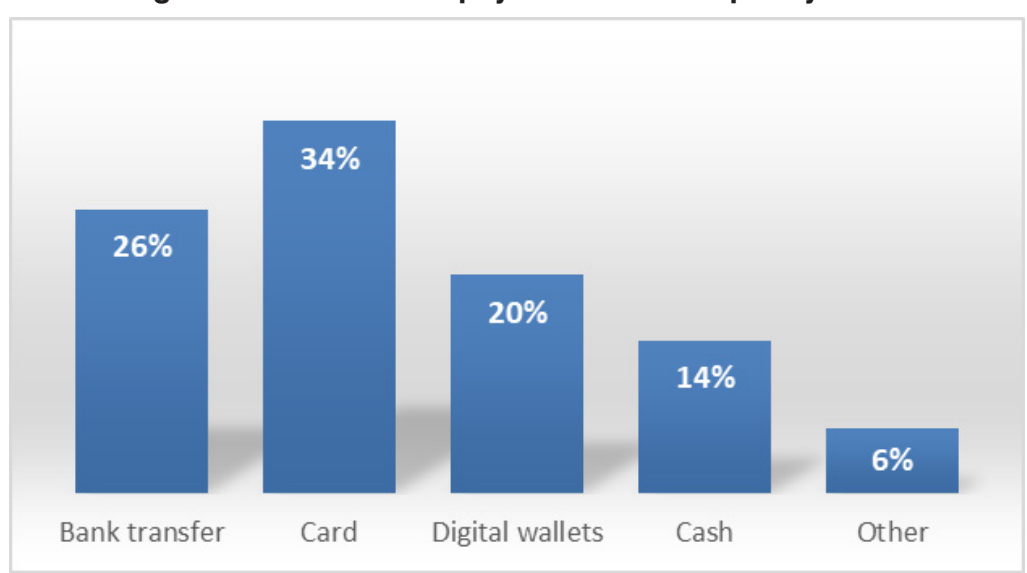

Source: JP Morgan 2019 Payments Trends - Global Insights Report: data provided by JP Morgan Merchant Services by Edgar, Dunn and Company, 2019. 


\subsection{Digital Payment Value Chain}

To be able to make the way into these mobile phone owners, new startup companies and fintech are becoming more IT-savvy and built their way through the payment value chain. According to a report by Deloitte (2019), the future of digital payments involve five key players and should consider aspects in the value chain to be sustainable. These five players are:

1. Customer: the end-user or or sender who initiates the payment

2. Merchant: the receiver who receives payments from the customer, and pays fees to the acquirer in exchange for its services.

3. Issuer: Typically a bank or financial institution that issues payment solutions to the customer, provides underwriting for the credit issue, and holds overall responsibility for end-user acquisition and engagement.

4. Acquirer: Typically a financial institution or aggregator that acquires merchants, provides them with the means to accept digital payments, and underwrites credit solutions.

5. Network provider: It connects all parties in the network, provides clearing and settlement functions, and manages risk in exchange for fees from both the issuer and the acquirer.

The impact of technological innovations on these main players in the payment value chain is shown in fig. 4 below:

Figure 4. The Payment Value Chain, Players and Impact

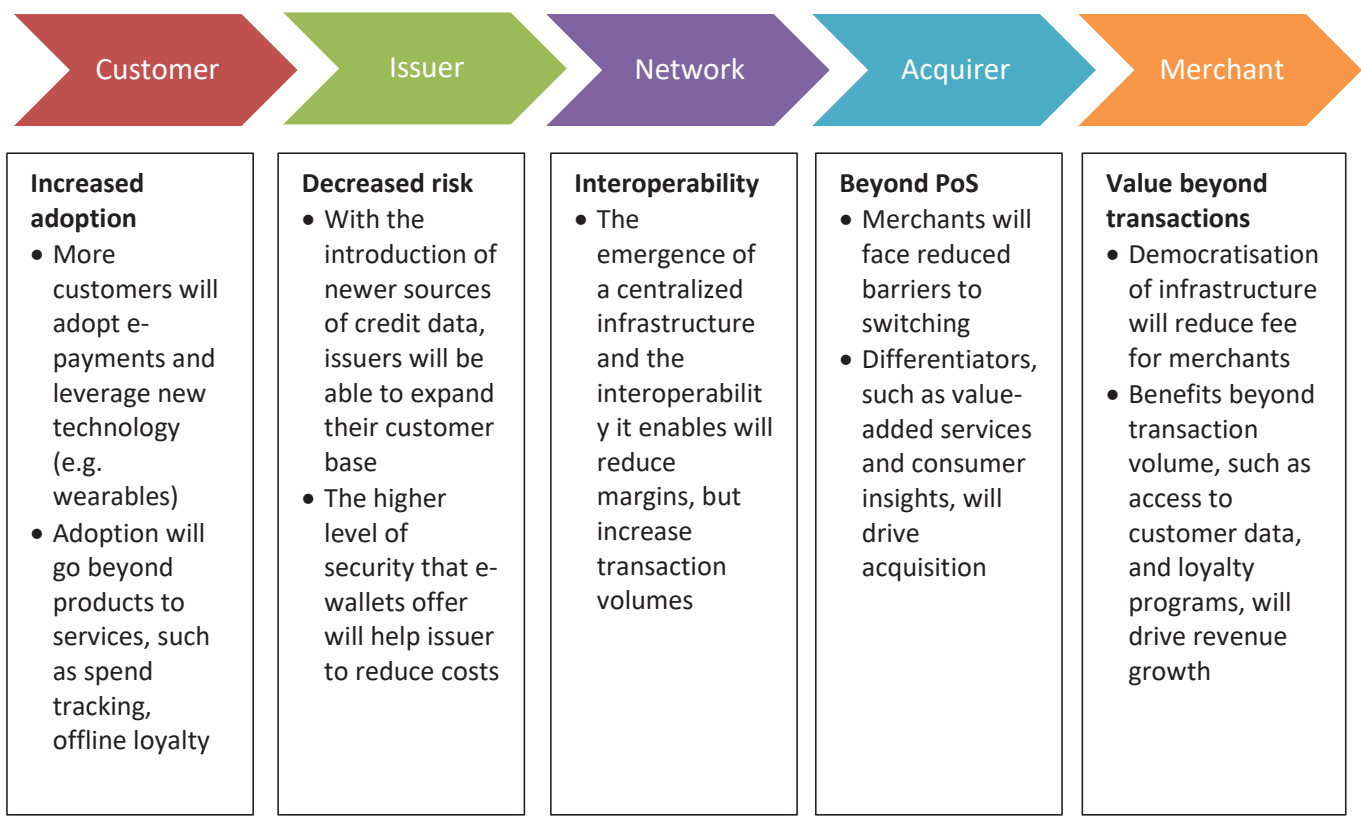

Source: Deloitte, 2019

According to the Bank of Indonesia (2018), as many as 95 million adults in Indonesia still lack an account at a traditional financial institution or a mobile money provider. Indonesia stands as the fourthlargest unbanked population after China, India and Pakistan (Global Findex, 2018). Rapid smartphone adoption and easy-to-use 
e-payment apps are penetrating Indonesia's vast unbanked population on a scale that the country's traditional banking industry has never been able to achieve. Fig. 5 shows how rapidly e-money transactions developed in Indonesia until the first half of 2018.

Figure 5. eMoney Transactions Development from 2012 to 2018

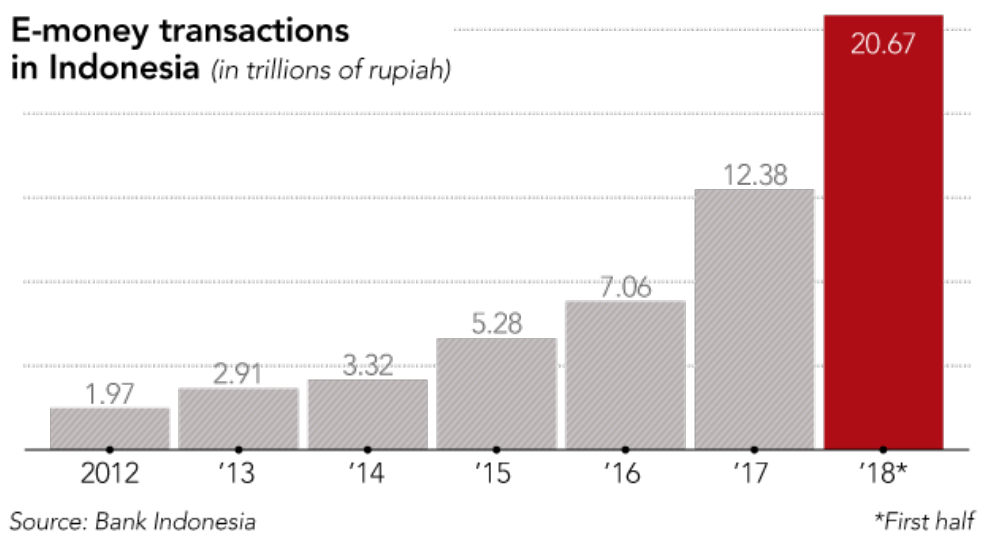

\section{Methodology and Results}

\subsection{Methodology}

The methodology for ths review paper is based on a survey conducted by IPSOS in December 2019 to map the digital financial market in Indonesia. In the IPSOS marketing summit, IPSOS summarized the findings of the survey. The survey was conducted online in 2019 among 1,000 respondents in Indonesia, between ages 18 to 50 , who owns a bank account, conducting financial transactions at least once a month, have internet access, and aware of e-wallet apps such as OVO, Go-Pay, and others. The result of this study indicated that $21 \%$ of consumers only use one e-wallet, whereas $28 \%$ use two e-wallet apps and $47 \%$ use three or more e-wallets. Respondents use e-wallets mainly for daily transactions such as online shopping, payment of bills, payment at restaurants, food delivery, payment for public transportation, payment for toll roads, online transportation services, and other digital banking services. The most used e-wallets are OVO and Go-pay, which provides the basis of e-wallet examples for comparison in this review paper.

The findings show that $68 \%$ of consumers surveyed use e-wallets at least once a week and $32 \%$ claim to use cash less frequently, after experiencing the convenience of cashless transactions. While most $(71 \%)$ consumers surveyed were initially motivated to use digital wallets because of promotions, the majority (68\%), have chosen convenience as the main driver for using e-wallets, followed by promotions $(23 \%)$ and security $(9 \%)$. GoPay is chosen by the majority of consumers $(54 \%)$ as the e-wallet they would continue to use, over others, without the presence of promotions.

\subsection{Factors Behind the Rise of e-wallets in Indonesia}

Innovations developed by non-financial instutions are reshaping the payment landscape. This is where agile new companies like Go-Jek and Grab entered the market. The top two e-payment players in Indonesia take advantage of the fact that more Indonesians own mobile phones than bank accounts. According to Statista (2019), Indonesia 


\section{Articles}

is one of the most sought-after markets globally for e-commerce, taking into account its population of 267 million people, with large local players and global heavyweights fighting for this enormous growing market. In 2017, about 20 million people were shopping online; this number was forecast to increase to 65 million by 2022. Primarily accessing the internet through mobile devices, it is estimated that more than half of all smartphone users in Indonesia purchase goods and services online. Besides their websites, most of the top e-commerce companies also have mobile applications allowing users to shop online through mobile devices.

Figure 6. Number of Smartphone Users in Indonesia from 2017 to 2022

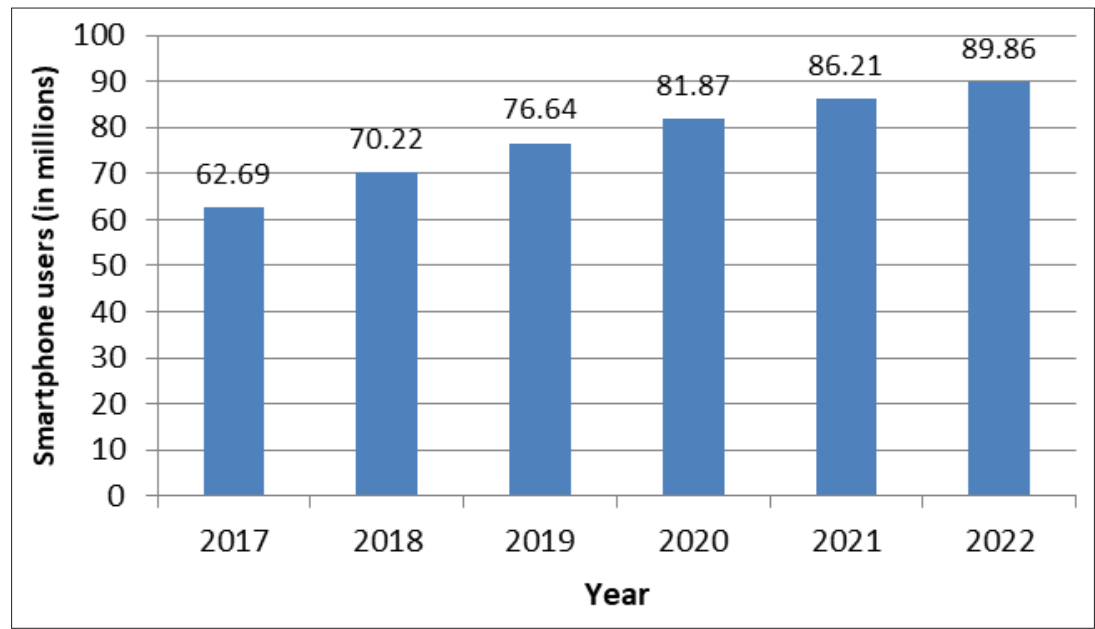

Source: Edited from statista.com, 2019

Based on growing smartphone use and worsening traffic jams in major Indonesian cities, Go-Jek, one of Indonesia's main startup unicorns, has quickly evolved from a motorbike taxi-hailing service to a provider and facilitator of a wide array of services, including food and parcel deliveries, and cleaners, beauticians and masseuses on call. Its app has been downloaded more than 96 million times, and the company partners with more than 1 million drivers. In April 2016, GoJek ventured into financial technology with the launch of Go-Pay. The convenience of paying and tipping drivers with an e-wallet created a large, growing user base: half of Go-Jek's 100 million monthly transactions are processed through Go-Pay. Later in 2017, GoJek partnered with Bank Nasional Indonesia (BNI), one of Indonesia's state-owned banks, to expand into lending for small and medium businesses by providing data of 125,000 restaurants that partner for Go-Jek's food delivery service, Go-Food. By partnering with $\mathrm{BNI}$, the bank can determine which business are eligible for government subsidized loans for microcredit called Kredit Usaha Rakyat or KUR.

Grab is a competitor for Go-Jek in providing rides. Lippo Group, which runs small lender Nobu Bank, originally relied on its own retail businesses to promote OVO, the e-payment platform it launched in early 2017. Lippo realized that if OVO stands alone, it will not be competitive, therefore partnering with a transport apps make it possible to reach a larger market share. When OVO was integrated into the Grab app in 2017, it began to gain market share. According to 


\section{Articles}

Nikkei Asian Review (2018), nowadays OVO has 13 million registered users and 250,000 transactions per day.

Another digital wallet, Tcash, rides on the vast network of its parent company, stateowned Telekomunikasi Selular, or Telkomsel, which is Indonesia's largest mobile operator with 178 million subscribers as of 2018 . With $97 \%$ of Indonesia's mobile subscribers on prepaid plans, Telkomsel has longestablished relationships with small telecom kiosks scattered across the country that sell its airtime and data packages. Tcash recruits these kiosks as its agents, offering people a new way to pay monthly bills, make motorcycle installments and transfer money, among other services. However, despite being the first to introduce mobile payments in Indonesia, Tcash is overtaken by Go-Jek and OVO due to practical aspects, since people are using mobile wallets to pay rides through the apps.
The Development of Digital Payment Systems in Indonesia: a Review of Go-Pay and Ovo E-Wallets

\subsection{Comparison of Go-Pay and OVO e-wallet Platforms}

The most used mobile wallets that serve as Indonesia's digital payment are Go-Jek's Go-Pay and Grab's OVO. Both platforms, GoJek and Grab, emerged from commuting or transportation apps, in which nowadays these apps are not limited not only to provide rides but other services such as ordering food, shopping, digital payments, local delivery services and many more. Go-Pay and OVO have the largest transaction ecosystem for mobile money in Indonesia, but Go-Pay remains popular as the first-mover advantage and takes the head start in mobile money transactions in Indonesia. Recently, a number of offline merchants accept this method of payment and the development of mobile money remains dynamic until now.

Table 3. A Comparison of Go-Pay and OVO e-wallets

\begin{tabular}{|c|c|c|}
\hline Description & Go-Pay & ovo \\
\hline As an apps & $\begin{array}{l}\text { Go-Pay is an e-wallet that is integrated to Go-Jek } \\
\text { transportation apps }\end{array}$ & $\begin{array}{l}\text { OVO is an independent digital platform, but } \\
\text { cooperates with Grab transportation apps }\end{array}$ \\
\hline Service applications & $\begin{array}{l}\text { Go-Pay e-wallet can only be used within the services } \\
\text { provided in Go-Jek apps }\end{array}$ & $\begin{array}{l}\text { Since OV0 e-wallet is an independent digital } \\
\text { platform, it has a wider scope of services }\end{array}$ \\
\hline Features & $\begin{array}{l}\text { Go-Pay can be used to pay Go-Jek online } \\
\text { transportation apps }\end{array}$ & $\begin{array}{l}\text { OV0 can be used to pay Grab online transporation } \\
\text { apps }\end{array}$ \\
\hline $\begin{array}{l}\text { Promotions and } \\
\text { discounts }\end{array}$ & $\begin{array}{l}\text { Go-Pay offers cashback and discounts in merchants } \\
\text { included in the service }\end{array}$ & $\begin{array}{l}\text { OVO offers cashback and discounts in a wider choice } \\
\text { of merchants }\end{array}$ \\
\hline Top-up & $\begin{array}{l}\text { - Top-ups can be done through: } \\
\text { - Transfer to/from Go-Pay users } \\
\text { - Go-Jek drivers } \\
\text { - } 24 \text { hour convenience stores } \\
\text { - Mobile banking } \\
\text { - Internet banking } \\
\text { - ATMs } \\
\text { - SMS banking }\end{array}$ & $\begin{array}{l}\text { - Top-ups can be done through: } \\
\text { - Transfer to/from OVO users } \\
\text { - Interbank transfers } \\
\text { - Debit cards } \\
\text { - ATMs } \\
\text { - Mobile banking } \\
\text { - Internet banking } \\
\text { - Some merchants e.g. convenience stores, } \\
\text { supermarkets, department stores, coffee shops, } \\
\text { gas stations }\end{array}$ \\
\hline Maximum balance & $\begin{array}{l}\text { Maximum balance users can keep in Go-Pay: } \\
2,000,000 \text { IDR for unregistered users } \\
10,000,000 \text { IDR for registered users (premium) } \\
\text { Maximum 20,000,000 IDR for transactions }\end{array}$ & $\begin{array}{l}\text { Maximum balance users can keep in OV0: } \\
2,000,000 \text { IDR for unregistered users } \\
\text { 10,000,000 IDR for registered users (premium) } \\
\text { Maximum 20,000,000 IDR for transactions }\end{array}$ \\
\hline Security aspects & PIN code & $\begin{array}{l}\text { Security code } \\
\text { Fingerprint }\end{array}$ \\
\hline
\end{tabular}

Source: Edited from www.cekaja.com 
Figure 7. The Apps Page of Go-Pay and OVO in Mobile Phones

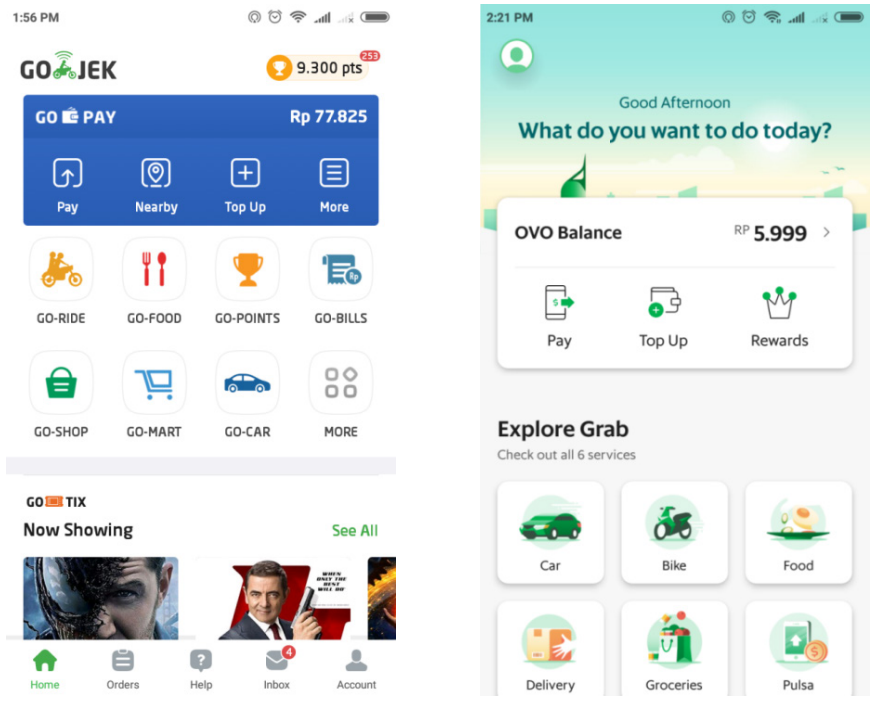

Source: www.gojek.com and www.grab.com

While Go-Pay is leading in terms of transaction volume and the most popular choice for Indonesian users according to IPSOS (54\%), Go-Pay only works in Go-Jek's own ecosystem of services and merchants. In contrast, OVO ranks in second place with 29\% of users (IPSOS, 2019). A main advantage of OVO is that the balance in Grab's OVO wallet can also be used it in the networks of other OVO partners outside of Grab's reach. OVO was developed by PT Visionet, a subsidiary of retail and property conglomerate Lippo Group. This has helped OVO spread its acceptance points to many shops and retail stores.

A previous research from Susilo, et. al. (2019), attempted to find out the factors of users choosing Go-Pay or OVO using TAM (Technology Acceptance Model) with 3 aspects in consideration: perceived usefullness, perceived ease of use, attitude toward using, and actual system use. The result of this study mentioned that TAM failed to capture the main causes why somebody tends to use Go-Pay or OVO more often. So when comparing which apps is preferable to users, the findings show indifference in choice, regardless of the promotions offered by both apps.

\section{Conclusion}

Users of both e-wallets, Go-Pay and OVO, have their own preferences in their choice, regardless of the features or promotions that each app provides. Convenience seems to be tthe main driver for users to use e-wallets, but further study needs to be conducted. As the competition between Go-Pay and OVO increases, in whch both apps are hoping to gain a strong market share in Indonesia, the government should be able to regulate e-wallets by being actively involved, given the regulation infrastructure that is already wellestablished by the Bank of Indonesia, OJK, the Ministry of Finance and the Ministry of Telecommunications. Simultaneously, the government should also play the role as an accelerator, to accelerate and introduce agile and dynamic policies, and to build good ecosystem and environment. The existence 


\section{Articles}

of e-wallets will be the future of Indonesia's cashless society, and the government needs to keep up with rapid change by making flexible and adaptable regulations in the digital finance environment.

\section{References}

Bank Indonesia. 2020. Payment System Regulation. [Online] https://www.bi.go.id/en/ peraturan/sistem-pembayaran/Default.aspx (accessed March 5, 2020).

Deloitte. 2019. Financial Service Authority (OJK) and Banking Regulations Update. [Online] https://www2.deloitte.com/content/ dam/Deloitte/id/Documents/audit/id-aud-ojkbanking-regulations-sep2019.pdf (accessed March 5, 2020)

Deloitte. 2019. The Future of Digital Payments: Choices to Consider for a New Ecosystem. [Online] https://www2.deloitte.com/content/ dam/Deloitte/sg/Documents/financialservices/sg-fsi-future-of-digital-payments.pdf (accesses February 4, 2020).

Damasha, K. 2019. Perbandingan Gopay dan OVO yang Perlu Diketahui. Siapakah yang Terbaik? [Online] https://www.cekaja.com/ info/perbandingan-gopay-dan-ovo-yangperlu-diketahui-siapakah-yang-terbaik/ (accessed March 30, 2020)

Demirguc-Kunt, A., Klapper, L., Singer, D., Ansar, S., \& Hess, J. (2018). The Global Findex Database 2017: Measuring Financial Inclusion and the Fintech Revolution. The Global Findex Database 2017: Measuring Financial Inclusion and the Fintech Revolution. https://doi.org/10.1596/978-1-4648-1259-0

Fadila, A. 2020. KONTAN: Dompet digital mana yang paling banyak dipakai di Indonesia? [Online] https://keuangan.kontan.co.id/news/ dompet-digital-mana-yang-paling-banyakdipakai-di-indonesia?page=all (accessed March 30, 2020)

FintechNews, 2019. Financial Inclusion Indonesia: The Digital Ecosystems That Will
The Development of Digital Payment Systems in Indonesia: a Review of Go-Pay and Ovo E-Wallets

Help Indonesia Reach 80\% Financial Inclusion [Online] https://fintechnews.sg/35731/ indonesia/the-digital-ecosystems-that-willhelp-indonesia-reach-80-financial-inclusion (Accessed March 2, 2020).

FintechNews, 2019. Southeast Asia's Booming Internet Economy to Boost Fintech Growth. [Online] https://fintechnews.sg/34248/studies/ southeast-asia-booming-internet-economyto-boost-fintech-growth (Accessed March 2, 2020).

Go-Jek website: https://www.gojek.com/

Grab website for OVO: https://www.grab.com/ id/en/pay/

IPSOS, 2020. Press Release: Consumer demand for convenient digital payments in Indonesia has reached a scale at which heavy promotions might no longer be necessary. [Online] https://www.ipsos.com/sites/default/ files/ct/news/documents/2020-02/ipsos_-press_release_-_english.pdf (Accessed March 20, 2020)

J.P. Morgan Payment Trends. 2019. E-Commerce Payment Trends: Indonesia [Online] https://www.jpmorgan.com/merchantservices/insights/reports/indonesia. (Accessed March 2, 2020)

Kapron Asia, 2019. How has OVO Become One of Indonesia's Top Digital Wallets? [Online] https://www.kapronasia.com/asiapayments-research-category/how-has-ovobecome-one-of-indonesia-s-top-digitalwallets.html (Accessed February 5, 2020)

KrAsia, 2018. Features and Functions of GoPay vs OVO, Side by Side. [Online] https:// $\mathrm{kr}$-asia.com/features-and-functions-of-gopay-vs-ovo-side-by-side (Accessed March 20, 2020).

McKinsey \& Company, 2019. Global Payments Report 2019: Amid sustained growth, accelerating challenges demand bold actions. [Online] https://www.mckinsey.com/ / media/mckinsey/industries/financial $\% 20$ 
services/our $\% 20$ insights/tracking $\% 20$ the $\% 20$ sources $\% 20$ of $\% 20$ robust $\% 20$ payments $\% 20$ grow th $\% 20$ m ckinsey $\% 20$ global $\% 20$ payments $\% 20$ map/global-payments-report2019-amid-sustained-growth-vf.ashx. (Accessed February 5, 2020)

Metra Digital Innovation. 2018. Mobile Payments in Indonesia: Race to Big Data Domination [Online] https://www.mdi.vc/ mobilepaymentindonesia.pdf

(Accessed March 2, 2020).

Muller J. 2019. Indonesia: Number of Internet Uses 2017-2023 [Online] Statista: https://www. statista.com/statistics/254456/number-ofinternet-users-in-indonesia/ (accessed March 5, 2020).

Muller, J. 2019. Indonesia: Number of Smartphone Users 2011-2022 [Online] Statista: https://www.statista.com/ statistics/266729/smartphone-users-inindonesia/ (accessed March 5, 2020).

Nikkei Asia Review, 2018. Go-Jek Sparks an Indonesian Banking Revolution. [Online] https://asia.nikkei.com/Spotlight/Cover-Story/ Go-Jek-sparks-an-Indonesian-bankingrevolution (Accessed February 5, 2020)

Otoritas Jasa Keuangan (OJK), Indonesia' Financial Services Authority (2019). Digital
Financial Inclusion in Indonesia [Online] https://www.ojk.go.id/id/berita-dan-kegiatan/ publikasi/Documents/Pages/Materi-OJKPROKSI-2016/7.Digital\%20Financial\%20 Inclusion\%20-\%200JK.pdf

Raharja, S., Sutarjo, Muhyi, H. A., and Herawaty, T. 2020. Digital Payment as an Enabler for Business Opportunities: A Go-Pay Case Study. Review of Integrative Business and Economics Research. Vol. 9. Supplementary Issue No. 1, pp. 319-329.

Susilo, A., Prabowo, M., Taman, A., Pustikaningsih, A., and Samlawi, A. 2019. A Comparative Study of Factors Affecting User Acceptance of GO-PAY and OVO as a Feature of Fintech Application. Procedia Computer Science. 161. 876-884. 10.1016/j. procs.2019.11.195.

The Asean Post, 2019. Indonesia: An e-commerce Success Story. [Online] https:// theaseanpost.com/article/indonesia-ecommerce-success-story (Accessed March 20, 2020)

Tayipnapis, A. Z., Wuryaningsih, L. E., and Gora, R. 2018. The Development of Digital Economy in Indonesia. International Journal of Management and Business Studies. Vol. 8. Issue No.3. 